\title{
Impact of post-infiltration soil aeration at different growth stages of sub-surface trickle-irrigated tomato plants**
}

\author{
Yuan Li ${ }^{1,3}$, Zong-xia Jia ${ }^{1}$, Wen-Quan Niu ${ }^{1,2,3 *}$, and Jing-wei Wang ${ }^{1,3}$ \\ ${ }^{1}$ Institute of Soil and Water Conservation, Northwest A and F University, Yangling, Shaanxi, China \\ ${ }^{2}$ Institute of Soil and Water Conservation, Chinese Academy of Sciences and Ministry of Water Resources, Yangling, \\ Shaanxi Province, 712100, China \\ ${ }^{3}$ Institute of Water-Saving Agriculture in Arid Areas of China (IWSA), Northwest A and F University, Yangling, Shaanxi, China \\ Received November 17, 2015; accepted May 30, 2016
}

\begin{abstract}
A b s t r a c t. Sensitivity to low rhizosphere soil aeration may change over time and therefore plant response may also depend on different growth stages of a crop. This study quantified effects of soil aeration during 5 different periods, on growth and yield of trickle-irrigated potted single tomato plants. Irrigation levels were 0.6 to 0.7 (low level) or 0.7 to 0.8 (high level) of total water holding capacity of the pots. Soil was aerated by injecting 2.51 of air into each pot through the drip tubing immediately after irrigation. Fresh fruit yield, above ground plant dry weight, plant height, and leaf area index response to these treatments were measured. For all these 4 response variables, means of post-infiltration aeration between 58 to 85 days after sowing were $13.4,43.5,13.7$, and $37.7 \%$ higher than those for the non-aerated pots, respectively. The results indicated that: post-infiltration soil aeration can positively impact the yield and growth of sub-surface trickle-irrigated potted tomato plants; positive effects on plant growth can be obtained with aeration during the whole growth period or with aeration for partial periods; positive growth effects of partial periods of aeration appears to persist and result in yield benefit.

$\mathrm{K}$ e y w o r d s: tomato, post-infiltration aeration, trickle irrigation
\end{abstract}

\section{INTRODUCTION}

Soil becomes close to saturation during, and immediately after, precipitation or irrigation (Niu et al., 2012a). Lowered soil aeration during these infiltration and postinfiltration periods can have an adverse effect on the growth and development of plant roots and shoots (Greenway et al., 2006; Heuberger et al., 2001; Niu et al., 2011; Vyrlas and Sakellariou-Makrantonaki, 2005). It has been shown that oxygen deficiency in the rhizosphere soil decreases the growth rate of roots, reduces nutrient and water uptake

*Corresponding author e-mail: nwq@vip.sina.com

**This work is supported jointly by China 863 Plan (2011AA100507), the National 111 Project of China (No. B12007). and significantly lowers crop yields (Chong et al., 2004; Pezeshki et al., 1993). Repeated exposure to periods of low rhizosphere soil aeration would be expected for subsurface trickle irrigation since water is usually applied at a lower amounts and higher frequencies than other forms of irrigation. Meek et al. (1983) showed that the rhizosphere soil oxygen content was higher under weekly drip irrigation or furrow irrigation than under daily drip irrigation.

Artificial aeration has been shown to promote root metabolism and growth (Bortolini, 2005; Niu et al., 2012b; Su and Midmore, 2005), enhance nutrient absorption, and soil redoxase enzyme activity (Brzezińska et al., 2001a, 2001b; Niu et al., 2012c), and accelerate the growth and yield of vegetables (Bhattarai et al., 2006; Nakano, 2007). Aeration through subsurface trickle irrigation tubes stimulated root growth (Bhattarai et al., 2006, 2008). Studies have indicated that continuous aeration, and aeration after irrigation, performed better than periodic intermittent aeration (Vyrlas and Sakellariou-Makrantonaki, 2005). Aerated irrigation once every 4 days substantially improved the root vigor and capacity of corn plants to absorb water and nutrients (Niu et al., 2011). Xie et al. (2010) showed that oxygenation of the root zone at fixed intervals increased the yield of greenhouse-produced sweet melon. Meek et al. (1983) reported higher yields of tomatoes were related to higher oxygen contents in the soil root zone before and during the fruit-enlarging stage.

These studies suggest that the magnitude of any positive effect of post-infiltration aeration for trickle-irrigated crops may not only depend on the species and irrigation level, but

(C) 2016 Institute of Agrophysics, Polish Academy of Sciences 
also on the growth stage. Since tomato plants are sensitive to low aeration caused by soil water saturation (Bradford, 1981), they have been used as test plants to investigate the effects of rhizosphere aeration on the growth and development (Bhattarai et al., 2006; Zhao et al., 2010). To date, no study has been reported on the sensitivity of tomato plants to low soil aeration at different growth stages, and how this may impact the growth and yield. However, such information would have practical value under different application levels in trickle-irrigated tomatoes if it shown that postinfiltration aeration is needed only at specific growth stages to overcome the negative effects of soil saturation.

In this study, we examined effects of aerating the soil during 5 different periods (namely 27-33, 34-57, 58-85, 86-99, and 27-99 days after sowing), on growth and yield of potted single tomato plants that were sub-surface trickleirrigated every 2 days at 2 levels.

\section{MATERIALS AND METHODS}

The experiment was conducted under a rain-shelter at the Key Laboratory of Water and Soil Engineering for Dry Regions of Northwest A \& F University located in Yangling, Shaanxi, China between April 7 and July 15, 2011. This study location is semi-arid with an average annual rainfall of $572.5 \mathrm{~mm}$, an average annual sunshine of $2163.8 \mathrm{~h}$, and 210 frost-free days.

On April 20, 3-week old tomato seedlings of variety 'Tianze Chunlei' were transplanted to 144 experimental pots. Each pot contained topsoil collected from the $0 \mathrm{~cm}$ to $20 \mathrm{~cm}$ depth of the Key Laboratory farmland (a Lou silty clay loam, soil order Inceptisol based on the USDA soil taxonomy). Three liters of water were added to each pot after transplanting. The pots with an upper inner diameter of $29 \mathrm{~cm}$, a bottom inner diameter of $22 \mathrm{~cm}$, and a depth of $24.5 \mathrm{~cm}$, were filled with soil to $22.5 \mathrm{~cm}$ to achieve a dry bulk density of $1.3 \mathrm{~g} \mathrm{~cm}^{-3}$. The total volume $(\mathrm{V})$ of soil in the pots was 9.8 liter calculated as the volume of a truncated right circular cone of large diameter $=25.2 \mathrm{~cm}(\mathrm{R})$, small diameter $=22 \mathrm{~cm}(\mathrm{r})$, and height $=22.5 \mathrm{~cm}$ (h) using the formula $\mathrm{V}=\left[\pi \mathrm{h}\left(\mathrm{R}^{2}+\mathrm{r}^{2}+\mathrm{Rr}\right)\right] / 3$. The topsoil initial moisture, total nitrogen, and organic matter content were $23.8 \%, 0.98$ and $9.51 \mathrm{~g} \mathrm{~kg}^{-1}$, respectively. The total porosity (n) of the silty clay loam soil in the pots was estimated as 1 minus the ratio of the dry bulk density $\left(\rho_{b}\right)$ to the particle density $\left(\rho_{p}\right)$. Using the measured $\rho_{b}=1.3 \mathrm{~g} \mathrm{~cm}^{-3}$ and taking $\rho_{p}=2.60 \mathrm{~g} \mathrm{~cm}^{-3}$ gave an estimated $\mathrm{n}=0.50$.

Every 2 days, starting April 27 (27 days after sowing), 72 pots were irrigated at 0.6 to 0.7 of the total water holding capacity (low level) and the other 72 pots at 0.7 to 0.8 of total water holding capacity (high level). The volume of water needed for the 2 irrigation levels was approximated through weighing (Chen et al., 2004) and recorded for each pot.
The five post-infiltration aeration periods by date and days after sowing (DAS) were: (1) the seedling stage between May 4 and 10 or 27 to 33 DAS, (2) the flowering and fruit setting stage between May 10 and June 3 or 34 -57 DAS, (3) the fruit enlarging stage between June 3 and July 1 or $58-85$ DAS, (4) the final fruit setting stage between July 1 and 15 or 86-99 DAS, and (5) the whole growing period between May 4 and July 15 or 27 to 99 DAS. During these post-infiltration aeration treatment periods, air was injected with an air compressor through the drip irrigation tubes buried at $18 \mathrm{~cm}$ in the pots at a rate of 2.5 liters per pot. This rate approximated $50 \%$ of the soil porosity in each pot. A no-aeration control was included for a total of 6 experimental treatments. For each irrigation level, each of the 6 treatments was applied to a block of 12 pots in a $6 \times 2$ factorial experiment.

The tomato plants were pruned to single stems, and were topped after the appearance of 4 trusses. Except for irrigation and aeration, the other management practices were the same for all pots. Three pots were randomly selected from each treatment block and used to obtain for ripe fruit yield (if any) and plant height measurement (using a steel ruler) at 33, 57, 85, and 99 DAS. At 99 DAS, the volume of water for the 38 irrigations applied to these 3 pots were totaled and averaged to obtain a mean value of water applied per pot $(\mathrm{n}=18)$ for the low and high irrigation levels.

Leaf area and above-ground plant dry weight at 33, 57 , and 85 DAS were obtained by destroying plants in 3 randomly selected pots from each treatment block. At 99 DAS the plants in the 3 remaining pots (that were earmarked for progressively measuring yield and height) were also destroyed for leaf area and dry weight measurement. Leaf area was measured with a LI-COR leaf area meter (LI-COR, Lincoln, Nebraska). The leaf area index (LAI) of the each plant was calculated as the measured leaf area $\left(\mathrm{cm}^{2} \mathrm{~cm}^{-2}\right)$ divided by the area of surface of the soil in the pot $\left(500 \mathrm{~cm}^{2}\right)$. The above ground dry weight was measured by drying in a forced air oven at $70^{\circ} \mathrm{C}$.

The experimental design was taken as a $2 \times 6$ factorial with 3 replicates. Accordingly, the data collected for each of the observed experimental variables was analyzed using the general linear model $Y_{i j k}=\mu+\alpha_{i}+\beta_{j}+(\alpha \beta)_{i j}+\varepsilon_{i j k}$ where $Y_{i j k}$ denotes the variable observed on the $\mathrm{k}^{\text {th }}$ replicate $(\mathrm{k}=1,2,3)$ for the $i$ th irrigation $(\mathrm{i}=1,2)$ and $\mathrm{j}^{\text {th }}$ aeration treatment $(j=1,2 \ldots 6)$. Here $\mu$ denotes the overall mean of the variable, $\alpha_{i}$ the effect of irrigation, $\beta_{j}$ the effect of post-infiltration aeration period, $(\alpha \beta)_{i j}$ the irrigation $\mathrm{x}$ postinfiltration aeration interaction effect, and $\varepsilon_{i j k}$ the associated random error. The fitting of the model was done using the 2-way ANOVA routine of the SPSS software package (IBM, Armonk, New York). 


\section{RESULTS AND DISCUSSION}

The post-infiltration aeration treatments did not significantly impact $(p>0.05)$ the fresh fruit yield of the potted tomato plants at either level of irrigation (Table 1). There was no irrigation $\mathrm{x}$ post-infiltration aeration interaction effect. The mean yield $(\mathrm{n}=18)$ across all aeration treatments was $674 \mathrm{~g}$ per plant at the low irrigation level and 680 $\mathrm{g}$ per plant at the high irrigation level. Nevertheless, all the post-infiltration aerated plant yields were higher than the no aeration treatment. For the low irrigation treatment, the mean yield $(\mathrm{n}=3)$ of the non-aerated plant was $616 \mathrm{~g}$ per plant compared to the mean yield for the of $688 \mathrm{~g}$ per plant for the pots that were aerated for the entire period of 27-99 days after sowing or about $12 \%$ higher. Corresponding values for the high irrigation treatment were 633 and $693 \mathrm{~g}$ per plant or about $9 \%$ higher. Even the short periods of post-infiltration aeration tended to increase fresh fruit yield. As shown in Table 1, aeration from 27 to 33 DAS resulted in a $10 \%$ yield increase from 616 to $680 \mathrm{~g}$ per plant for the low irrigation level. For the high irrigation level, there was a corresponding $8 \%$ increase from 633 to $683 \mathrm{~g}$ per plant. Lower increases of 6 and $4 \%$ over the no post-infiltration aeration treatment were obtained with aeration from 86 to 99 DAS (Table 1). Maximum yields of 709 and 710 g per plant were obtained for post-infiltration aeration during 58-85 days after sowing corresponding to the fruit setting period (Table 1). Nevertheless, these differences were statistically non-significant due to the high within-sample variability in yield for some of the aeration treatments.
Yields at the high irrigation level were slightly higher compared with those of the low irrigation level for all aeration treatments (Table 1). The highest difference of $17 \mathrm{~g}$ per plant (an increase of about 3\%) was obtained for non-aerated pots. The lack of any marked effect of irrigation level on fresh fruit yield suggests that there was very little difference between the soil water availability and accessibility between the two irrigation levels. The total porosity (n) of the silty clay loam soil in the pots was estimated as $n=0.50$. Rawls et al. (1982) reported the geometric mean bubbling pressure for 689 samples of silty clay loam soils was $33 \mathrm{~cm}$ water. Since the depth of soil in the pots was $22.5 \mathrm{~cm}$ and less than the bubbling pressure, there would be little or no tendency for gravitational water drainage and the soil was therefore close to saturation after free drainage. The total volume of soil in the pots was 9.81 . This implies that the total water holding capacity (at saturation) was equivalent to 4.91 of water in the pots. Rawls et al. (1982) reported the arithmetic mean volumetric water content \pm one standard deviation at $-1.5 \mathrm{MPa}$ soil water potential (considered as the permanent wilting point) for 689 samples of silty clay loam soils was $0.21 \pm 0.08$. Using the mean value gives estimated volumes of plant available water in the pots of 2.91 at total water holding capacity, between 0.9 and 1.41 at the low irrigation level (ie 0.6 to 0.7 of total water holding capacity), and between 1.4 and 1.91 at the high irrigation level (ie 0.7 to 0.8 of total water holding capacity). Thus

T a b l e 1. The effect of none or 2.51 post-infiltration aeration applied during 5 different growth periods (in days after sowing on the fruit yield (g per plant), above-ground plant dry weight ( $\mathrm{g}$ per plant), and plant height $(\mathrm{cm})$ of potted single tomato plants at 99 days after planting. Pots were subsurface drip-irrigated at 2-day intervals to maintain the soil at 60 to 70 and 70 to $80 \%$ of volumetric field capacity (denoted as low and high irrigation level)

\begin{tabular}{|c|c|c|c|c|c|c|c|c|c|}
\hline \multirow{3}{*}{$\begin{array}{c}\text { Aeration } \\
\text { period, days } \\
\text { after sowing }\end{array}$} & \multicolumn{9}{|c|}{ Irrigation level } \\
\hline & Low & High & \multirow{2}{*}{$\begin{array}{l}\text { Mean } \\
(n=6)\end{array}$} & Low & High & \multirow{2}{*}{$\begin{array}{l}\text { Mean } \\
(\mathrm{n}=6)\end{array}$} & Low & High & \multirow{2}{*}{$\begin{array}{l}\text { Mean } \\
(\mathrm{n}=6)\end{array}$} \\
\hline & \multicolumn{2}{|c|}{$\begin{array}{l}\text { Fruit yield } \\
\text { (g per plant) }\end{array}$} & & \multicolumn{2}{|c|}{$\begin{array}{l}\text { Plant dry weight } \\
\text { (g per plant) }\end{array}$} & & \multicolumn{2}{|c|}{$\begin{array}{l}\text { Plant height } \\
(\mathrm{cm})\end{array}$} & \\
\hline None & $616 a$ & $633 a$ & $625 a$ & $30.7 b$ & $36.0 \mathrm{a}$ & $33.3 \mathrm{c}$ & $78.2 d$ & $79.1 \mathrm{c}$ & $78.6 \mathrm{c}$ \\
\hline $27-33$ & $680 \mathrm{a}$ & $683 a$ & $681 \mathrm{a}$ & $40.2 \mathrm{ab}$ & $41.0 \mathrm{a}$ & $40.6 \mathrm{abc}$ & $80.5 \mathrm{~d}$ & $84.5 b$ & $82.5 b$ \\
\hline $34-57$ & $695 a$ & $704 a$ & $699 a$ & $42.2 \mathrm{a}$ & $52.3 \mathrm{a}$ & $47.3 \mathrm{a}$ & $88.8 \mathrm{ab}$ & $88.8 \mathrm{a}$ & $88.8 \mathrm{a}$ \\
\hline $58-85$ & $709 a$ & $710 \mathrm{a}$ & $709 a$ & $44.1 \mathrm{a}$ & $51.5 \mathrm{a}$ & $47.8 \mathrm{a}$ & $90.8 \mathrm{a}$ & $88.0 \mathrm{a}$ & $89.4 \mathrm{a}$ \\
\hline $86-99$ & $654 a$ & $659 a$ & $657 \mathrm{a}$ & $36.1 \mathrm{ab}$ & $37.9 \mathrm{a}$ & $37.0 \mathrm{bc}$ & $82.2 \mathrm{~cd}$ & $83.1 \mathrm{~b}$ & $82.7 \mathrm{~b}$ \\
\hline $27-99$ & $688 \mathrm{a}$ & $693 a$ & $691 \mathrm{a}$ & $40.5 \mathrm{ab}$ & $49.2 \mathrm{a}$ & $44.9 \mathrm{ab}$ & $85.0 \mathrm{bc}$ & $82.2 \mathrm{~b}$ & $83.6 \mathrm{~b}$ \\
\hline $\begin{array}{l}\text { Overall } \\
\text { mean }\end{array}$ & 674 & 680 & 677 & $39.0 \mathrm{ab}$ & 44.6 & 41.8 & 84.2 & 84.3 & 84.3 \\
\hline
\end{tabular}

Aeration treatment means across irrigation levels $(n=6)$ and at each irrigation level $(n=3)$ not followed by the same letter are significantly different at the $5 \%$ level. All irrigation treatment means for each aeration treatment period $(\mathrm{n}=3)$ and across aeration treatment periods $(n=18)$ were not significantly different. 
at low irrigation levels the spatially-averaged air-filled porosity varied from 0.15 to 0.20 by volume, while at high irrigation levels the spatially-averaged air-filled porosity ranged from 0.15 to 0.10 .

A 2-day irrigation frequency implies a supply of 0.45 to 0.7 liter per day of plant available water at the low irrigation level and 0.7 to 1.45 liter per day at the high irrigation level. The pots remaining at 99 DAS had each been irrigated 38 times between 27-99 DAS. The mean \pm standard deviation $(\mathrm{n}=18)$ for the total volumes of water applied per pot for the low irrigation was $36.9 \pm 2.2$ and $39.3 \pm 4.41$ for the high irrigation level. This implies an average irrigation rate of about $585 \mathrm{~cm}^{3}$ per pot per day for the low irrigation level and $624 \mathrm{~cm}^{3}$ per pot per day for the high irrigation level. Nahar and Ullah (2012) reported a transpiration rate averaged over the growing period of about 300 to $350 \mathrm{~cm}^{3}$ per day for single tomato plants grown in pots on a silty clay loam soil at a moisture content maintained at 0.7 of the measured field capacity ( 0.4 by volume). Therefore it is unlikely that there was inadequate soil water availability during the entire growth period in this experiment. Indeed, no wilting was observed in the plants at either the low nor high irrigation level.

In general, above ground plant dry weight and plant height at 99 DAS (Table 1) mirrored the yield response to the treatments. This would be expected since these three variables represent an integrated measure of the treatment effects on the plant over the entire growth period. The 2-way ANOVA showed no significant interaction between irrigation level and post-infiltration aeration treatments. Overall mean above ground plant dry weight for the high irrigation level was $14 \%$ higher than the lower level (Table 1). As was found for fresh fruit yield, post-infiltration aeration even for short periods resulted in above ground dry weight and plant height increases although these increases were statistically non-significant. Also, highest increases for plant dry weight and height over the no-aeration treatment occurred for the longer periods of post-infiltration aeration.

The foregoing results appeared to indicate a variable but positive impact of post-infiltration soil aeration at any growth stage. Increasing levels of drip irrigation at a given frequency would supply more soil water available for transpiration and generally this would positively increase growth and yield. On the other hand, increasing levels also lower post-infiltration soil aeration. All the experimental pots were irrigated a total of 38 times between 27 to 99 DAS with 5 applications between 27 to 33 DAS, 11 between 34 to 57 DAS, 15 between 57 to 85 DAS, and 5 between 86 to 99 DAS. As discussed above, given the $33 \mathrm{~cm}$ water bubbling pressure for the silty clay loam, it would be expected that the soil in the vicinity of the sub-surface drip emitters would be close to saturation immediately after irrigation. Since redistribution in finer textured soils is generally slow, this saturated zone would be expected to persist for some time after irrigation. This zone would also increase in size with increasing irrigation volumes need to compensate for consumptive use by the plants and maintain the target volumetric soil water content. Any positive effect of post-infiltration aeration would be related primarily on how well the injected air stream permeates this zone and promotes enhanced root activity and overall plant growth and development. This would be revealed by examining and comparing plant growth response to no aeration, aeration for the entire growing period, and the 4 partial period post-infiltration aeration treatments measured at the end of each aeration period, especially at the end of the two longer partial aeration periods (ie at 57 DAS and 85 DAS).

Table 2 shows the above ground plant dry weight measured at 57, 85, and 99 days after sowing (DAS) for the 6 post-infiltration aeration treatments (ie none or 2.51 aeration applied during 5 different periods) at the low and high irrigation levels (ie subsurface drip-irrigation to maintain soil at 0.6 to 0.7 and 0.7 to 0.8 of total water holding capacity). To facilitate comparisons, these observations at 57 and 85 DAS are presented in Table 2. The plant dry weight measured at 57 DAS for the low and high irrigation levels showed the same pattern across the 6 aeration treatments and supports the foregoing discussion of the negligible effect of the high and low irrigation levels on fruit yield.

As shown, at 57 DAS post-infiltration aeration for the entire growing period (ie 27 to 99 DAS) increased plant dry matter by about $11 \%$ compared to the no aeration treatment. As would be expected, the plant dry matter for the no post-infiltration aeration treatment was about the same for the later partial aeration periods ( 86 to 99 and 58 to 85 DAS) since at 57 DAS the pots for these treatments were not yet aerated. On the other hand, the plant dry weight for the pots aerated between 34 to 57 DAS was higher by about $13 \%$ than the non-aerated pots and was about the same as for the pots aerated for the entire 27 to 99 DAS (Table 2). The plant dry weight was close to $3 \%$ higher than the nonaerated pots even for the short post-infiltration aeration period (ie 27-33 DAS) after the plants were established. This suggests the possibility that even short periods of postinfiltration aeration can positively affect growth and yield.

This possibility is further confirmed by the observations of plant dry weight at 85 DAS (Table 2) for the low and high irrigation levels. As for the observations at 57 DAS, the pattern of plant dry weight response at 85 DAS was similar for both the low irrigation levels. The positive differences in values between the high and low irrigation levels were more marked at 85 DAS than at 57 DAS for all aeration treatments (Table 2).

As shown, plant dry weight at 85 DAS for all aeration treatments was higher than for the non-aerated treatment. Also, the non-significant between the non-aerated and the 86-99 DAS aeration treatment was expected since at 85 
T a b l e 2. Above-ground plant dry weight (g per plant) of potted single tomato plants $(n=3)$ measured at 57 , 85 , and 99 days after sowing (DAS) for the 6 post-infiltration aeration treatments (ie none or 2.51 aeration applied during 5 different periods) at the low and high irrigation levels (ie subsurface drip-irrigation to maintain soil at 60 to 70 and 70 to $80 \%$ of volumetric field capacity)

\begin{tabular}{|c|c|c|c|c|c|c|}
\hline \multirow{3}{*}{$\begin{array}{l}\text { Aeration period, } \\
\text { days after } \\
\text { sowing }\end{array}$} & \multicolumn{6}{|c|}{ Plant dry weight (g per plant) measured at DAS } \\
\hline & 57 & 85 & 99 & 57 & 85 & 99 \\
\hline & \multicolumn{3}{|c|}{ Low irrigation level } & \multicolumn{3}{|c|}{ High irrigation level } \\
\hline None & $16.6 \mathrm{a}$ & $22.5 \mathrm{a}$ & $30.7 \mathrm{~b}$ & $16.8 \mathrm{a}$ & $24.6 \mathrm{a}$ & $36.0 \mathrm{~b}$ \\
\hline $27-33$ & $17.1 \mathrm{a}$ & $26.6 \mathrm{a}$ & $40.2 \mathrm{ab}$ & $17.4 \mathrm{a}$ & $27.3 \mathrm{a}$ & $41.0 \mathrm{ab}$ \\
\hline $34-57$ & $18.7 \mathrm{a}$ & $30.2 \mathrm{a}$ & $42.2 \mathrm{a}$ & $19.0 \mathrm{a}$ & $31.6 \mathrm{a}$ & $52.3 \mathrm{a}$ \\
\hline $58-85$ & $16.7 \mathrm{a}$ & $31.7 \mathrm{a}$ & $44.1 \mathrm{a}$ & $17.1 \mathrm{a}$ & $33.5 \mathrm{a}$ & $51.5 \mathrm{a}$ \\
\hline $86-99$ & $16.7 \mathrm{a}$ & $23.9 \mathrm{a}$ & $36.1 \mathrm{ab}$ & $16.9 \mathrm{a}$ & $28.2 \mathrm{a}$ & $37.9 \mathrm{ab}$ \\
\hline $27-99$ & $18.5 \mathrm{a}$ & $28.7 \mathrm{a}$ & $40.6 \mathrm{ab}$ & $19.3 \mathrm{a}$ & $30.3 \mathrm{a}$ & $49.2 \mathrm{ab}$ \\
\hline Overall mean & 17.4 & 27.3 & 39.0 & 17.7 & 29.2 & 44.6 \\
\hline
\end{tabular}

Aeration treatment means $(n=3)$ at each irrigation level not followed by the same letter are significantly different at the $5 \%$ level.

DAS this was the only post-infiltration aeration treatment that had not yet been applied. It appears that the positive effect of the post-infiltration aeration applications during 27-33 DAS persisted until 85 DAS. At 85 DAS the dry weight for 27-33 DAS aeration treatment was close to $18 \%$ higher than the non-aerated plants for the low irrigation level and nearly $11 \%$ higher for the high irrigation level (Table 2). The values for the 58-85 DAS and the 34-57 DAS treatments further support the finding that positive effects of post-infiltration aeration tend to persist. As shown in Table 2, at 85 DAS there were non-significant differences between plant dry weight for the 34-57 DAS and 58-85 DAS aeration treatments.
As was found for the response variables discussed above, the 2-way ANOVA results (Table 3) for leaf area index (LAI) measured at 57, 85, and 99 days after DAS showed was no irrigation $\mathrm{x}$ post-infiltration aeration interaction effects. It showed there were highly significant $(p<0.01)$ aeration treatment effects on LAI at 57,85 , and 99 DAS. Irrigation means $(n=18)$ were not significantly different at 57 DAS $\left(0.55\right.$ versus $0.57 \mathrm{~cm}^{2} \mathrm{~cm}^{-2}$ for the low and high levels respectively). Although the dif ferences were small $(<9 \%)$ values at 85 DAS were ( 0.79 versus $0.86 \mathrm{~cm}^{2} \mathrm{~cm}^{-2}$ ) were significantly different at the $1 \%$ level $(p<0.01)$. Corresponding values at 99 DAS ( 0.39 versus $0.42 \mathrm{~cm}^{2} \mathrm{~cm}^{-2}$ ) were significantly different at

T a b l e 3. Leaf area index $\left(\mathrm{cm}^{2} \mathrm{~cm}^{-2}\right)$ of potted single tomato plants $(\mathrm{n}=3)$ measured at 57,85 , and 99 days after sowing (DAS) for the 6 post-infiltration aeration treatments (ie none or 2.51 aeration applied during 5 different periods) at the low and high irrigation levels (ie subsurface drip-irrigation to maintain soil at 60 to 70 and 70 to $80 \%$ of volumetric field capacity)

\begin{tabular}{|c|c|c|c|c|c|c|}
\hline \multirow{3}{*}{$\begin{array}{l}\text { Aeration period, } \\
\text { days after } \\
\text { sowing }\end{array}$} & \multicolumn{6}{|c|}{ Leaf area index $\left(\mathrm{cm}^{2} \mathrm{~cm}^{-2}\right)$ measured at DAS } \\
\hline & 57 & 85 & 99 & 57 & 85 & 99 \\
\hline & \multicolumn{3}{|c|}{ Low irrigation level } & \multicolumn{3}{|c|}{ High irrigation level } \\
\hline None & $0.45 \mathrm{c}$ & $0.70 \mathrm{~d}$ & $0.34 \mathrm{c}$ & $0.46 \mathrm{c}$ & $0.76 \mathrm{~b}$ & $0.35 \mathrm{~d}$ \\
\hline $27-33$ & $0.60 \mathrm{ab}$ & $0.74 \mathrm{~cd}$ & $0.38 \mathrm{bc}$ & $0.63 \mathrm{ab}$ & $0.78 b$ & $0.39 \mathrm{c}$ \\
\hline $34-57$ & $0.62 \mathrm{a}$ & $0.81 \mathrm{bc}$ & $0.40 \mathrm{bc}$ & $0.71 \mathrm{a}$ & $0.92 \mathrm{a}$ & $0.45 \mathrm{ab}$ \\
\hline $58-85$ & $0.54 \mathrm{abc}$ & $0.94 \mathrm{a}$ & $0.47 \mathrm{a}$ & $0.62 \mathrm{ab}$ & $1.02 \mathrm{a}$ & $0.48 \mathrm{a}$ \\
\hline $86-99$ & $0.49 \mathrm{bc}$ & $0.71 \mathrm{~d}$ & $0.35 \mathrm{bc}$ & $0.48 \mathrm{bc}$ & $0.77 b$ & $0.39 \mathrm{c}$ \\
\hline $27-99$ & $0.58 \mathrm{ab}$ & $0.86 \mathrm{ab}$ & $0.41 \mathrm{~b}$ & $0.49 \mathrm{bc}$ & $0.89 \mathrm{ab}$ & $0.43 b$ \\
\hline Overall mean & 0.55 & 0.79 & 0.39 & 0.57 & 0.86 & 0.42 \\
\hline
\end{tabular}

Aeration treatment means $(n=3)$ at each irrigation level not followed by the same letter are significantly different at the $5 \%$ level. 
the $5 \%$ level (Table 3). Leaf area is a precise measurement with low within sample variability and this would tend to produce statistically significant differences vis-a-vis integral response measures such as fresh fruit yield and above ground dry weight.

Aeration treatment effects, at each irrigation level were quite consistent with those for above ground dry weight primarily. In general, LAI values at 57,85 , and at 99 DAS were not significantly different between the no aeration and aeration for the 86-99 DAS treatment at both low and high irrigation levels (Table 3). On the other hand, LAI values for the other 4 aeration treatments (ie 27-33, 34-57, 58-85, and 27-99 DAS) were higher at all 3 measurement dates than those for the no aeration and for 86-99 DAS aeration treatments. Differences tended to be more marked for LAI at 57 and 85 DAS compared to 99 DAS (Table 3). This is not unexpected since as shown in Table 3 many leaves had already senesced and dropped off resulting in LAI values that were $50 \%$ less than the values measured at 85 DAS.

The foregoing treatment effects generally support findings in some previous studies. Bhattarai et al. (2006) showed that aeration promoted leaf area expansion. Previous studies (Sun et al., 2008a, 2008b; Niu et al., 2011) suggested that aeration had cumulative and persistent effect on leaf development. As shown in Table 3, aeration during portions of the growth period tended to produce similar LAI measurements as those for the continuous aeration.

Favorable soil gas environment reduces root $\mathrm{ABA}$ (abscisic acid) synthesis, while reducing the ABA contents in leaves. The ABA which leads to stomatal closure is intensely studied, there was a positive correlation between ABA and stomatal resistance (Bai et al., 2013; Comstock, 2002; Loverys et al., 1987). Plant root zone aeration led to the reduction of $\mathrm{ABA}$ in their leaves, and the reduction of ABA can directly promote the photosynthetic rate, so the leaf area index increased. Higher photosynthetic rate and leaf area index both guarantee for increasing yield. However, aeration treatments indirectly affect fruit yield. This is why the aeration treatments significantly impact on LAI but not significantly effect on the fruit yield.

\section{CONCLUSIONS}

1. The post-infiltration aeration treatments did not significantly impact the fresh fruit yield of the potted tomato plants at either level of irrigation. Nevertheless, all the post-infiltration aerated plant yields were higher than the no aeration treatment.

2. Post-infiltration soil aeration affected the plant dry weight, plant height and leaf area index of sub-surface trickle-irrigated potted tomato plants at 99 days after planting. Post-infiltration aeration, applied during 27-33DAS, 34-57 DAS, 58-85 DAS, 86-99 DAS, and 27-99 DAS, the plant dry weight increased by $22,42,43,11$, and $35 \%$, respectively than the no aeration treatment; Plant height increased by $5,13,14,5$, and $6 \%$, respectively than the no aeration treatment; Leaf area index increased by 12,25 , 39,9 , and $23 \%$, respectively than the no aeration treatment.

3. Positive growth effects of partial periods of aeration appears to persist and result in yield benefit. If conclusively demonstrated this would result in lowering time and cost-effectiveness associated with post-infiltration aeration practices.

Conflict of interest: The Authors do not declare conflict of interest.

\section{REFERENCES}

Bai T.H., Li C.Y., Chao L., Liang D., and Ma F.W., 2013. Contrasting hypoxia tolerance and adaptation in Malus species is linked to differences in stomatal behavior and photosynthesis. Physiol Plant., 147, 514-523.

Bhattarai S.P., Midmore D.J., and Pendergast L., 2008. Yield, water-use efficiencies and root distribution of soybean, chickpea and pumpkin under different subsurface drip irrigation depths and oxygation treatments in vertisols. Irrigation Sci., 26, 439-450.

Bhattarai S.P., Pendergast L., and Midmore D.J., 2006. Root aeration improves yield performance and water use effciency of tomato in heavy clay and saline soils. Sci. Hortic., 108, 278-288.

Bortolini L., 2005. Injecting air into the soil with buried fertirrigation equipment. Informatore Agrario, 61(19), 33-36.

Bradford K.J. and Yang S.F., 1981. Physiological responses of plants to water logging. HortScience, 16, 25-30.

Brzezińska M., Stępniewska Z., Stępniewski W., Przywara G., and Wlodarczyk T., 2001a. Effect of oxygen deficiency on soil dehydrogenase activity (pot experiment with barley. International Agrophysics, 15(1), 3-7.

Brzezińska M., Stępniewska Z., Stępniewski W., Przywara G., and Wlodarczyk T., 2001b. Effect of oxygen deficiency on soil dehydrogenase activity in a pot experiment with triticale $c v$. Jago vegetation. International Agrophysics, 15(3), 145-149.

Chen J.P., Liu Z.G., Duan A.W., Meng Z.J., and Zhang J.Y., 2004. Effects of soil moisture on physiological characteristics and the dynamic state of factors causing photosynthesis decline in potted tomato leaves in green house. Acta Botanica Boreali-occidentalia Sinica, 24(9), 1589-1593.

Chong S.K., Boniak R., Indorante S., Ok C.H., and Buschschulte D., 2004. Carbondioxide content in golf green rhizosphere. Crop Science, 44, 1337-1340.

Comstock J.P., 2002. Hydraulic and chemical signalling in the control of stomatal conductance and transpiration. J. Exp. Bot., 53, 195-200.

Greenway H., Armstrong W., and Colmer T., 2006. Conditions leading to high $\mathrm{CO}_{2}(>5 \mathrm{kPa})$ in waterlogged-flooded soils and possible effects on root growth and metabolism. Annals Botany, 98, 9-32.

Heuberger H., Livet J., and Schnitzler W., 2001. Effect of soil aeration on nitrogen availability and growth of selected vegetables preliminary results. Acta Horticulturae, 563, 147-154. 
Loverys B.R., Robinson S.P., and Downton W.J.S., 1987. Seasonal and diurnal changes in abscisic acid and water relations of apricot leaves. New Phytol., 107, 15-27.

Meek B.D., Ehlig C.F., Stolzy L.H., and Graham L.E., 1983. Furrow and trickle irrigation: Effects on soil oxygen and ethylene and tomato yield. Soil Sci. Soc. Am. J., 47(4), 631-635.

Nahar K. and Ullah S.M., 2012. Morphological and physiological characters of tomato (Lycopersicon esculentum mill) cultivars under water stress. Bangladesh J. Agric. Res., 37(2), 355-360.

Nakano Y., 2007. Response of tomato root systems to environmental stress under soilless culture. Japan Agri. Res. Quarterly, 41, 7- 15.

Niu W.Q., Guo C., Shao H.B., and Wu P.T., 2011. Effects of different rhizosphere ventilation treatment on water and nutrients absorption of maize. African J. Biotechnology, 10(6), 949-959.

Niu W.Q., Guo Q., Zhou X.B., and Helmers M.J., 2012a. Effect of aeration and soil water redistribution on the air permeability under subsurface drip irrigation. Soil Sci. Soc. Am. J., $76,815-820$

Niu W.Q., Jia Z.X., Zhang X., and Shao H.B., 2012b. Effects of soil rhizosphere aeration on the root growth and water absorption of tomato. Clean-Soil, Air, Water, 40(12), 1364-1371.

Niu W.Q., Zang X., Jia Z.X., and Shao H.B., 2012c. Effects of rhizosphere ventilation on soil enzyme activities of potted tomato under different soil water stress. Clean-Soil, Air, Water, 40(3), 225-232.

Pezeshki S.R., Pardue J.H., and Delaune R.D., 1993. The influence of soil oxygen deficiency on alcohol dehydrogenase activity, root porosity, ethylene production and photosynthesis in Spartina patens. Environ. Exp. Bot., 33(4), 565-573

Rawls W.J., Brakensiek D.L., and Saxton K.E., 1982. Estimating soil water properties. Transactions ASAE, 25(5), 1316-1320.

Su N.H. and Midmore D.J., 2005. Two-phase flow of water and air during aerated subsurface drip irrigation. J. Hydrology, $313,158-165$.

Sun Z.P., Guo Z.M., and Liu Y.L., 2008a. Measurement of rhizospheric $\mathrm{CO}_{2}$ and $\mathrm{O}_{2}$ concentrations of potato plant in the field and the responses to different rhizospheric ventilation treatments (in Chinese). Acta Agriculturae Boreali-occidentalis Sinica, 17(4), 125-128.

Sun Z.P., Guo Z.M., and Wang H., 2008b. Effects of different rhizosphere ventilation treatments on photosynthetic and physiological indices of potato. Acta Agriculturae BorealiSinica, 23(3), 125-128.

Vyrlas P. and Sakellariou-Makrantonaki M., 2005. Soil aeration through subsurface drip irrigation. Proc. 9th Int. Conf. Environmental Sci. Technology Vol. B-Poster Presentations, September 1-3, Rhodes Island, Greece.

Xie H.X., Cai H.J., and Zhang Z.H., 2010. Evaluation of comprehensive benefit in greenhouse muskmelon under aeration irrigation. Trans. Chinese Soc. Agric. Machinery, 41(11), 79-84.

Zhao X., Li T.L., and Sun Z.P., 2010. Effects of substrateaeration cultivation pattern on tomato growth. Chinese J. Applied Ecology, 21(1), 74-78. 